\title{
Problematika Hak Kekayaan Intelektual Di Bidang Merek Bagi Pelaku Usaha Mikro Kecil Menegah
}

\author{
Zulfikri Toguan \\ Fakultas Hukum, Universitas Islam Riau, Indonesia. E-mail: zulfikripohan@law.uir.ac.id
}

\begin{abstract}
Legal protection for a mark of a place or origin of MSMEs can be done by first registering the mark to obtain legal force. In this case the Office/Agency/Community Organization assists by facilitating MSMEs in terms of socialization and assistance for trademark registration. Law Number 20 of 2016 concerning Marks and Geographical Indications provides improvements to previous laws, especially regarding preventive protection measures, namely registration procedures and registration fees. Brands produced by Indonesian MSMEs can help increase competitiveness in the development of new products. This research is normative or library research method, namely legal research carried out by reviewing and researching library materials in the form of primary legal materials and secondary legal materials. This study concludes: First, the problems in the protection of intellectual property rights in the field of branding for MSME products are due to the understanding of MSME actors on brand rights is still low/shallow so that MSME actors do not register the brand of MSME products. Second, efforts to provide brand protection to the MSME industry are by registering MSME brands and the government makes it easy for MSME industry players to register trademarks.
\end{abstract}

Keywords: Problematics, Brand, Micro, Small and Medium Enterprises

\section{Pendahuluan}

Dewasa ini permasalahan hak kekayaan intelektual menjadi sorotan dan bahan kajian yang mendapat perhatian dari berbagai pihak, baik nasional maupun internasional. Masalahnya adalah bahwa milik inteletual tidak semata-mata berkaitan dengan hukum saja, melainkan erat hubungannya dengan masalah perdagangan, ekonomi, pengembangan teknologi serta menjadi landasan bagi usaha untuk memajukan sosiokultural bangsa dan masyarakat pada umumnya. ${ }^{1}$

HKI dan produk perdagangan memiliki hubungan yang sangat erat. Untuk sampai ketangan konsumen, produk perdagangan yang berkaitan dengan invensi dalam bidang teknologi memerlukan Hak atas Paten, sedangkan untuk membedakan kualitas produk perdagangan dari sisi keterjaminan original dan labeling maka diperlukannya Hak atas Merek, dan dalam halnya membentuk suatu kreasi berwujud yang berkaitan dengan seni pada produk perdagangan, agar kreasi tersebut memiliki kekuatan yang tetap maka

\footnotetext{
${ }^{1}$ Harsono Adi Suamarto, Hak Milik Intelektual Khusunya Paten, dan Merek, Akademik Presindo, Jakarta, 1990, hlm. 6.
} 
diperlukan Hak atas Desain. Dari penjabaran diatas dapat disimpulkan bahwa produk perdagangan memiliki hubungan keterkaitan dengan HKI dari awal proses produksi hingga sampai ke tangan konsumen.

Dalam dunia perdagangan, merek sebagai salah satu bentuk kekayaan intelektual telah digunakan sejak ratusan tahun yang lalu dan mempunyai peranan yang penting dalam membedakan asal usul barang dan jasa. Sebuah merek dapat menjadi kekayaan yang sangat berharga secara komersial dan seringkali mereklah yang membuat harga suatu produk menjadi mahal bahkan lebih bernilai dibandingkan dengan perusahaan tersebut. ${ }^{2}$

Perkembangan kegiatan perdagangan barang dan jasa di Indonesia dalam beberapa tahun terakhir ini mengalami peningkatan yang cukup signifikan karena perkembangan teknologi informasi dan sarana transportasi yang menyebabkan aktivitas di sektor perdagangan, baik barang maupun jasa mengalami perkembangan yang sangat pesat. Kecenderungan meningkatnya arus perdagangan barang dan jasa akan terus berlangsung sejalan dengan pertumbuhan ekonomi nasional yang semakin meningkat.

Merek sebagai salah satu karya intelektual manusia yang akrab hubungannya dengan kegiatan ekonomi dan perdagangan memegang peranan yang sangat penting. ${ }^{3}$ Dengan merek, produk barang atau jasa sejenis dapat dibedakan asal muasalnya, kualitasnya serta jaminan bahwa produk itu orisinal. Kadangkala yang membuat suatu produk itu menjadi mahal bukan karena produknya itu sendiri, tetapi karena mereknya. ${ }^{4}$

Khususnya mengenai hak merek secara eksplisit disebut sebagai benda immaterial dalam konsiderans Undang-Undang Nomor 20 tahun 2016 tentang Merek dan Indikasi Geografis, bagian "Menimbang" butir a, yang berbunyi :"Bahwa didalam era persagangan global, sejalan dengan konvensi - konvensi internasional yang telah diratifikasi Indonesia, peranan merek menjadi sangat penting, terutama dalam menjaga persaingan usaha yang sehat, berkeadilan, pelindungan konsumen, serta pelindungan Usaha Mikro, Kecil, dan Menengah dan industri dalam negeri."

Kementerian Koperasi dan UMKM menyebutkan bahwa UMKM yang berkembang saat ini terbagi menjadi beberapa kategori yaitu pertanian, peternakan, perikanan, kehutanan, listrik, gas, air bersih, perdagangan, hotel, restoran, jasa-jasa swasta, dan industri pengolahan yang salah satunya mencakup industri kreatif.

Dalam pelaksanaan pembangunan ekonomi diberlakukan upaya-upaya, antara lain meningkatkan, memperluas, menetapkan, dan mengamankan segala bentuk produk baik

\footnotetext{
${ }^{2}$ Richard Burton Simatupang, Aspek Hukum Dalam Bisnis, Asdi Mahasatya, Jakarta, 2003, hlm. 86.

${ }^{3}$ Ibid., hlm. 87.

${ }^{4}$ Tulus Tambunan, Perekonomian Indonesia Beberapa Masalah Penting, Ghalia Indonesia, Jakarta, 2003, hlm. 307.
} 
barang maupun jasa termasuk aspek investasi dan hak atas kekayaan intelektual yang berkaitan dengan perdagangan serta meningkatkan kemampuan daya saing terutama dalam perdagangan internasional.

Indonesia merupakan Negara yang sebagian besar dana pemasukanya berasal dari UMKM (Usaha Mikro Kecil dan Menengah) ehingga UMKM menjadi salah satu faktor yang memiliki peranan besar dalam meningkatkan devisa negara. Produk-produk yang diproduksi oleh UMKM di Indonesia banyak yang bernilai ekonomi tinggi dan memiliki keunikan terutama apabila sudah masuk dalam pasar luar negeri.

Karena kurangnya kepekaan dan tidak memberikan perlindungan terhadap produk yang dimiliki, pada akhirnya banyak dari produk-produk Indonesia khususnya produk-produk yang memiliki nilai tradisional yang ide-ide dan desainnya dicuri oleh pihak luar. Mungkin bangsa Indonesia kurang menyadari bahwa perlindungan HKI membawa nilai ekonomi yang tinggi apabila sudah masuk dalam dunia perdagangan. ${ }^{5}$

Seringakali terjadi sengketa merek muncul lantaran beberapa hal, antara lain karena pengusaha tidak segera mendaftarkan mereknya sehingga dimanfaatkan pihak lain, ataupun sengketa yang disebabkan adanya pihak yang tidak beritikad tidak baik yang dengan sengaja mendaftarkan merek-merek terkenal atau menguntungkan, untuk tujuan mendompleng kepopuleran atau mencari kompensasi uang/ganti rugi di kemudian hari, Sebenarnya pengusaha-pengusaha di Indonesia terutama pengusaha UMKM sudah semakin sadar akan pentingnya mendaftrakan merek produknya. ${ }^{6}$

UMKM merupakan pelaku ekonomi nasional yang mempunyai peran yang sangat penting dalam pembangunan perekonomian. Perlindungan Hak Kekayaan Intelektual (HKI) atas usaha mikro kecil dan menengah (UMKM) memegang peran penting dalam era globalisasi. Upaya perlindungan dapat dilakukan dengan cara pengajuan pendaftaran atas produkproduk UMKM yang memenuhi syarat untuk dapat diberikan HKI sehingga konsekuensinya, pemerintah / Negara akan memberikan perlindungannya seperti paten, hak cipta, merek, desain industri, serta rahasia dagang.

Manfaat perlindungan HKI terhadap UMKM antara lain dapat meningkatkan nilai tambah bagi produk serta pengusaha termasuk perolehan atas hak istimewa yang dipegang oleh UMKM. Penumbuhan kesadaran masyarakat terhadap HKI dalam UMKM perlu diupayakan terus menerus agar terciptanya produk UMKM yang mampu bersaing dalam pasar bebas dan menghadapi Masyarakat Ekonomi Asean (MEA).

\footnotetext{
${ }^{5}$ Syafrinaldi, Hukum Tentang Perlindungan Hak Milik Intektual Dalam Menghadapi Era Gllobalisasi, UIR Press, Pekanbaru, 2006, hlm. 10.

${ }^{6}$ Candra Purnama, Perlindungan Hukum Produk Umkm Melalui HKI (Hak Kekayaan Intelektual), Staf Dinas Koperasi Dan UMKM, Jakarta, 2010, hIm.49.
} 
Dalam melindungi mereknya UMKM mengalami beberapa kesulitan yaitu masih rendahnya kesadaran UMKM untuk mendaftrakan mereknya, karena tidak mengetahui manfaat dari pendaftaran merek, pihak UMKM merasa dengan mendaftarkan mereknya akan mengeluarkan biaya yang sangat besar dimana ratarata UMKM ini merupakan usaha menengah kebawah. UMKM bertujuan untuk menumbuhkan dan mengembangkan usaha dalam rangka membangun perekonomian nasional berdasarkan demokrasi ekonomi yang berkeadilan. ${ }^{7}$

Kedudukan Indonesia yang demikian, memerlukan dorongan serta pengawasan secara langsung dari pemerintah agar sektor UMKM dapat meningkatan kinerja dan kualitas yang berdampak langsung pada penerapan HKI.

Oleh sebab itu, persaingan antar Negara menjadi semakin ketat sehingga bangsa Indonesia dituntut untuk mempersiapkan sedemikian rupa dalam kegiatan perindustrian terkait kekuatan dan kesadaran masyarakat terhadap HKI

Berdasarkan uraian di atas, maka dapat dirumuskan permasalahan sebagai berikut;

1. Apa Problematika Dalam Perlindungan Hak Kekayaan Intelektual Di Bidang Merek Terhadap Produk UMKM?

2. Bagaimana Upaya Perlindungan Hukum Hak Kekayaan Intelektual Bidang Merek Terhadap Produk UMKM di Indonesia?

\section{Metode}

Dalam penelitian ini penulis menggunakan metodologi yang dianggap paling sesuai dengan keadaan objek penelitian ini, sebagai berikut,

Dilihat dari jenisnya maka penelitian ini dapat digolongkan kepada penelitian hukum normatif atau metode penelitian kepustakaan yakni penelitian hukum yang dilakukan dengan cara mengkaji dan meneliti bahan-bahan pustaka berupa bahan hukum primer dan bahan hukum sekunder. ${ }^{8}$ Pemilihan metode ini, sebagaimana yang dijelaskan oleh Peter Mahmud Marzuki, karena penelitian hukum adalah suatu proses untuk menemukan aturan hukum, prinsip hukum, dan doktrin hukum untuk menjawab isu hukum yang dihadapi. Penelitian ini bersifat analistis-eksploratif yakni melalui bahanbahan kepustakaan. ${ }^{9}$

Dalam penelitian hukum normatif sumber data berasal dari data sekunder. Data sekunder dalam jenis penelitian ini terbagi menjadi tiga jenis data, yaitu bahan hukum primer, bahan hukum sekunder, dan bahan hukum tertier. Bahan hukum primer adalah bahan hukum yang berasal dari:

\footnotetext{
${ }^{7}$ Syafrinaldi, Perlindungan Merek Terkenal Di Indonesia Di Era Globalisasi, Jurnal Mahkamah, Volume. 2, Nomor 1, 2010, hlm. 7.

${ }^{8}$ Soerjono Soekanto dan Sri Mamudji, Penelitian Hukum Normatif Suatu Tindakan Singkat, Raja Grafindo, Jakarta, 2007, hlm. 13-14

${ }^{9}$ Peter Mahmud Marzuki, Penelitian Hukum edisi revisi, Kencana Pranada Media Group, Jakarta, 2015, hlm. 164
} 
a. Undang-undang Dasar RI 1945

b. Undang-undang Undang-Undang Nomor 20 Tahun 2016 tentang Merek dan Indikasi Geografis

c. Undang-Undang Nomor 20 Tahun 2008 tentang Usaha Mikro, Kecil, dan Menengah

Bahan hukum sekunder, yakni bahan-bahan hukum yang memberikan penjelasan bahan hukum primer yang berpa rancangan undang-undang, hasil-hasil penelitian, hasil karya ilmiah dari kalangan ahli hukum, dan sebagainya.

Bahan hukum tertier, merupakan bahwa bahan yang memberikan petunjuk maupun penjelasan. ${ }^{10}$ seperti, Kamus Besar Bahasa Indonesia, kamus hukum dan artikel-artikel yang dapat membantu penelitian ini.

Pengumpulan data dalam penelitianhukum normatif hanya digunakan teknik studi dokumenter/studi kepustakaan. Dalam keadaan tertentu dapat digunakan teknik wawancara nonstruktur yang berfungsi sebagai penunjang saja bukan sebagai alat untuk mendapatkan data primer.

Setelah melalui proses pengumpulan data dan pengolahan data, kemudian data dianalisis secara deskriftif kualitatif, teknik analisis ini tidak menggunakan angka-angka statistik, namun lebih kepada penjelasan dalam bentuk kalimat yang dipaparkan secara lugas. Data yang telah dianalisis dan dideskripsikan selanjutnya disimpulkan dengan metode deduktif yakni menyimpulkan dari pernyataan yang bersifat umum kedalam pernyataan yang bersifat khusus.

\section{Hasil dan Pembahasan}

\section{Problematika Dalam Perlindungan Hak Kekayaan Intelektual Di Bidang Merek Terhadap Industri UMKM}

Merek merupakan salah satu kekayaan industri. Suatu produk tidak akan dapat terlepas dari suatu merek, karena merek merupakan identitas dari produk tersebut. Merek adalah aset ekonomi bagi pemiliknya, baik perorangan maupun perusahaan (badan hukum) yang dapat menghasilkan keuntungan besar, tentunya bila didayagunakan dengan memperhatikan aspek bisnis dan proses manajemennya yang baik. Demikian pentingnya peranan merek ini, maka terhadapnya dilekatkan perlindungan hukum, yakni sebagai objek terhadapnya terkait hak-hak perseorangan atau badan hukum. ${ }^{11}$

Perlindungan merek sangat penting sekali, Merek berfungsi sebagai tanda pengenal yang menunjukkan asal barang dan jasa, sekaligus menghubungkan barang dan jasa yang bersangkutan dengan produsennya. Merek selain sebagai harta kekayaan yang dapat menghasilkan keuntungan bagi pengusaha selaku pemilik merek, juga sebagai alat untuk melindungi masyarakat selaku konsumen dari terjadinya penipuan kualitas barang tertentu. Konsumen akan meresa dirugikan jika merek yang mereka anggap berkualitas, ternyata diproduksi oleh pihak lain dengan kualitas rendah. ${ }^{12}$

\footnotetext{
10 Soerjono Soekanto dan Sri Mamudji, Penelitian Hukum ..., Op.Cit., hlm. 12

${ }^{11}$ Adrian Sutedi, Hak Atas Kekayaan Intelektual, Sinar Grafika, Jakarta, 2009, hlm. 92

12 Khoirul Hidayah, Hukum Hak Kekayaan Intelektual, Setara Press, Malang, 2017, hlm. 54.
} 
Merek menggambarkan jaminan kepribadian (individuality) serta reputasi suatu barang dan jasa hasil usaha sewaktu diperdagangkan. Jaminan kualitas suatu barang atau jasa sangat berguna bagi produsen dalam persaingan usaha dan sekaligus memberikan perlindungan jaminan produknya kepada konsumen.

Dirjen HKI mengemukakan bahwa pemakaian Merek berfungsi sebagai tanda pengenal untuk membedakan hasil produksi yang dihasilkan seseorang atau beberapa orang secara bersama-sama atau badan hukum dengan produksi orang lain atau badan hukum lainnya, kemudian sebagai alat promosi sehingga mempromosikan hasil produksinya cukup dengan menyebut Mereknya, sebagai jaminan atas mutu barangnya, dan sebagai penunjuk asal barang atau jasa yang dihasilkan.

Beberapa problematika yang terjadi dalam terhadap perlindungan hak kekayaan intelektual bidang merek bagi pelaku UMKM meliputi sebagai berikut;

a. Kurangnya wawasan para pengusaha home industry eggroll tentang merek serta prosedur pendaftarannya

Para pelaku usaha UMKM banyak yang belum mengetahui tentang pentingnya suatu pendaftaran merek serta prosedur dalam mendaftarkannya. Shingga hal tersebut menyebabkan pelaku UMKM tidak mendaftarkan merek produk UMKM yang di hasilkan atau diproduksi atas usaha yang dimilikinya.

Pelaku UMKM lainnya menuturkan bahwa mereka masih bingung dengan proses atau prosedur pendaftaran hak merek produk mereka, mereka hanya tahu bahwa mengurus hal tersebut dilakukan di Jakarta. Sementara mengenai berkas-berkas serta tata caranya mereka masih awam. ${ }^{13}$

Adapula pemahaman terkait budaya para pelaku UMKM, bahwa produk atau nama boleh saja sama tetapi rasa memiliki ciri khas sendiri-sendiri. Sehingga mereka menggagap pendaftaran merek tidak menjadi hal utama selama para konsumen mampu mengenali produk mereka dengan baik dan proses perdagangan pelaku UMKM tetap terjaga baik dan makin berkembang. Mereka beranggapan hal ini dirasa cukup tanpa harus mendaftarkan hak merek produk mereka.

b. Kurangnya penyuluhan dan sosialisasi dari Pemerintah Daerah

Sistem Pemerintahan daerah saat ini telah bersifat otonom sehingga suatu daerah bisa mengatur daerahnya sendiri. Sebagai daerah otonom, Pemerintah daerah belum bisa mengadakan suatu penyuluhan sendiri di Kabupaten dikarenakan kurangnya biaya serta belum adanya tenaga ahli di bidang HKI khusunya merek.

Kurangnya sosialisasi yang dilakukan mengenai pentingnya pendaftaran merek oleh pelaku UMKM menyebabkan tidak sampainya informasi yang tepat, akurat dan jelas mengenai pentingnya hak merek, keadaan ini akan memberikan penafsiran yang keliru terhadap peranan perlindungan merek dalam memberikan perlindungan bagi produk UMKM. Jalur pendistribusian informasi yang tidak

\footnotetext{
13 lbid., hlm. 55.
} 
sampai tersebut ke sasaran, sehingga kesadaran untuk melakukan pendaftaran merek juga tidak akan ada. ${ }^{14}$

c. Prosedur pendaftaran merek yang terlalu lama

Jangka waktu pendaftaran suatu merek memerlukan waktu sekitar dua tahun untuk mendapatkan sertifikat merek. Prosedur yang lama ini membuat para UMKM tidak sabar serta tidak melakukan pendaftaran merek hasil UMKM yang dimilikinya.

d. Khawatir akan biaya pendaftaran merek yang mahal

Biaya atau tarif pendaftaran HKI khususnya tentang merek memang memerlukan dana yang tidak sedikit. elaku UMKM khawatir kalau nanti merek mereka didaftarkan maka akan terkena biaya yang mahal seperti dalam pengurusan izin PIRT dan SIUP.

e. Kurangnya anggaran dana dan tenaga ahli dalam bidang HKI di Pemerintah Daerah

Dana yang dibutuhkan oleh Pemerintah Daerah khususnya pada Dinperindagkop sangat kurang. Anggaran yang dipergunakan untuk suatu penyuluhan dan sosialisasi dalam bidang HKI khusunya merek belum ada. Kekurangan dalam masalah dana ini ditambah lagi masalah yaitu belum adanya tenaga ahli yang benar-benar tahu dalam bidang HKI khususnya merek UKM kurang mempunyai inisiatif dan kreatifitas untuk membuat nama merek dan mendaftarkannya Banyak UKM yang telah mempunyai berbagai merek produk dan pemasarannya telah menjangkau banyak daerah tetapi mereka masih malas dan tidak mempunyai inisiatif sendiri untuk mendaftarkan mereknya.

Pentingnya pendaftaran merek terhadap pelaku usaha di Indoneisa belum secara menyeluruh disadari oleh kelas-kelas pelaku usaha. Di Indonesia terdapat kelas pelaku usaha seperti Usaha Mikro, Kecil dan Menengah (UMKM) yang mana secara persentase masih sedikit yang telah mendaftarkan merek ke Dirjen KI dibandingkan dengan pelaku usaha Non-UMKM. Sebagaimana data yang telah diuraikan sebelumnya yakni data statistik pendaftaran Ditjen KI menunjukkan bahwa selama periode 2016-April 2018 pendaftaran Merek Non UMKM mendominasi sebesar 91,45\% sedangkan untuk merek UMKM hanya sebesar $8.55 \%$.

Oleh karena itu perlindungan hukum atas merek menjadi sangat penting agar tidak digunakan oleh pihak lain secara melawan hukum seperti pemalsuan, peniruan yang dapat menciptakan persaingan dagang tidak sehat dan pada akhirnya akan merugikan pemilik merek. Untuk memperoleh perlindungan hukum atas merek tersebut, maka dengan demikian maka Merek harus didaftarkan terlebih dahulu. Dirjen KI mengemukakan bahwa pendaftaran merek berfungsi sebagai alat bukti bagi pemilik yang berhak atas Merek yang didaftarkan, sebagai dasar penolakan terhadap Merek yang sama keseluruhan atau sama pada pokoknya yang dimohonkan pendaftaran oleh orang lain untuk

\footnotetext{
${ }^{14}$ F. Yudhi Priyo Amboro, Problematika Pendaftaran Merek Untuk Usaha Mikro, Kecil dan Menengah di Kota Batam, Journal of Judicial Review, Volume XXI, Nomor 1, 2019, hlm. 22.
} 
barang atau jasa sejenisnya, dan juga berfungsi sebagai dasar untuk mencegah orang lain memakai Merek yang sama keseluruhan atau sama pada pokoknya dalam peredaran untuk barang atau jasa sejenisnya. ${ }^{15}$

\section{Upaya Perlindungan Hukum Hak Kekayaan Intelektual Bidang Merek Terhadap Produk UMKM di Indonesia}

Undang-Undang Merek No. 20 tahun 2016 tentang Merek dan Indikasi Geografis tidak banyak membahas terkait dengan Merek UMKM di Indonesia. Penyebutan terkait dengan Merek UMKM tertuang di dalam konsideran huruf a UU Merek 2016 yang berisikan "bahwa di dalam era perdagangan global, sejalan dengan konvensi internasional yang telah diratifikasi Indonesia, peranan Merek dan Indikasi Geografis menjadi sangat penting terutama dalam menjaga persaingan usaha yang sehat, berkeadilan, pelindungan konsumen, serta pelindungan Usaha Mikro Kecil dan Menengah, dan industri dalam negeri;". ${ }^{16}$

Berdasarkan konsideran tersebut, dapat diketahui bahwa fokus dari UU Merek 2016 adalah memberikan kepastian hukum dan perlindungan terutama kepada konsumen dan pelaku usaha dalam negeri, dan menjaga suatu persaingan usaha yang sehat. Hanya saja, persaingan usaha yang sehat hanya bisa dapat terjadi apabila para industri besar tidak memanfaatkan posisi dominannya untuk menekan industri UMKM melainkan mereka harus bisa bersinergi dalam menjalankan suatu roda perekonomian secara bersama-sama tanpa melakukan monopoli. ${ }^{17}$

Keberadaan UU Merek 2016 diharapkan bisa menjadi salah satu cara pemerintah dalam melindungi usaha UMKM melalui perlindungan kekayaan intelektualnya yang berupa Merek. Dengan adanya pengakuan Merek yang diberikan kepada pelaku usaha UMKM maka industri besar ataupun para pelaku usaha yang memiliki itikad tidak baik, tidak serta merta dapat mengambil kekayaan intelektual milik pelaku usaha UMKM karena kepemilikan Merek yang terdaftar diakui dan dilindungi oleh pemerintah. Apabila ada sengketa yang lahir akibat adanya sengketa kepemilikan Merek, pemerintah hanya akan mengacu sertifikat Merek sebagai bukti kepemilikan hak atas Merek, kecuali terjadi pembatalan hak atas merek berdasarkan gugatan merek yang dilakukan oleh salah satu pihak di pengadilan Niaga.

Kemudian sebagai upaya perlindungan hukum terhadap merek industri UMKM di Indonesia dilakukan dengan cara meningkatkan industri UMKM untuk mendaftarkan merek oleh pelaku UMKM. dikarenakan industri UMKM hanya akan mendapatkan perlindungan hukum merek apabila telah mendaftarkan mereknya. Upaya yang telah dilakukan yakni dengan cara:

a. Biaya Registrasi Merek UMKM yang Lebih Murah Dibandingkan Merek NonUMKM

\footnotetext{
${ }^{15}$ Asti Wulan Adaninggar, Hendro Saptono, Kholis Roisah, Perlindungan Produk Usaha Mikro Kecil Dan Menengah Terkait Hak Kekayaan Intelektual Dalam Menghadapi Masyarakat Ekonomi Asean, Law Journal, Volume 5, Nomor 3, Tahun 2016, 39.

${ }^{16}$ Konsideran Undang-Undang No. 20 tahun 2016 tentang Merek dan Indikasi Geografis.

${ }^{17}$ Adrian Sutedi, Hak Atas..., Op.Cit., hlm. 94
} 
Kecilnya pendaftar Merek UMKM tidak membuat pemerintah tinggal diam. Pemerintah melalui Dirjen KI terus mendorong untuk meningkatkan pendaftaran Merek dari industri UMKM dengan membebankan biaya yang jauh lebih murah dibandingkan dengan pendaftar Merek Non UMKM.

Hal tersebut menunjukkan kepedulian pemerintah untuk meningkatkan perkembangan bisnis UMKM dengan menjaga kekayaan intelektual dari para pelaku bisnis UMKM. Sebuah merek terdaftar dilindungi sehingga orang lain tidak dapat memakainya dan akan mendapatkan perlindungan selama sepuluh (10) tahun dari tanggal penerimaan pendaftaran sebagaimana diatur dalam Pasal 35 UU No. 20 tahun 2016 tentang Merek dan Indikasi Geografis. Jangka waktu ini dapat diperpanjang untuk masa yang tidak ditentukan selama sepuluh (10) tahun dengan pembayaran biaya. Namun, pemilik, harus mengajukan perpanjangan 12 bulan sebelum merek tersebut berakhir. Merek akan diperpanjang masa berlakunya hanya jika pemilik masih memakai merek tersebut dalam perdagangan barang dan/atau jasa. ${ }^{18}$

Dirjen KI memberikan perlakuan khusus bagi industri UMKM dalam mendukung industri UMKM untuk mendaftarkan merek yakni dengan memberikan pembedaan harga registrasi yang lebih murah dibandingkan dengan pelaku usaha umum. Berikut disajikan perbandingan harga registrasi permohonan pendaftaran merek antara merek UMKM dan merek umum.

Tidak hanya terhadap permohonan pendaftaran merek saja, tetapi juga terhadap biaya perpanjangan perlindungan merek atau merek kolektif terdaftar antara merek UMKM dan umum juga diberikan perbedaan harga. Berikut disajikan perbandingan harga registrasi perpanjangan perlindungan merek antara merek UMKM dan merek umum.

b. Kerjasama antara Ditjen KI Kementerian Hukum dan Ham dan Kementerian Koperasi dan UMKM

Upaya yang telah dilakukan untuk memberikan perlindungan Merek dagang produksi industri UMKM diadakan Kerjasama antara Departemen Hukum dan HAM RI dengan Kementrian Koperasi dan Usaha Kecil Dan Menengah RI Nomor M-10-UM .06.07.TH 2006 tentang Peningkatan Pemahaman dan Pemanfaatan Sistem Hak Kekayaan Intelektual yang di dalamnya terdapat perlindungan merek dagang bagi Koperasi dan UMKM. Adapun pertimbangan diadakan kerjasama tersebut adalah sebagai berikut: ${ }^{19}$

1) UMKM merupakan salah satu pelaku usaha yang memiliki kontribusi yang nyata dalam perekonomian nasional.

2) Pengetahuan dan pemahaman mengenai keberadaan dan pentingnya pemanfaatan sistim Hak Kekayaan Intelektual (khususnya Hak Merek) di kalangan pelaku UMKM sektor industri baik makanan, miniman maupun barang-barang produksi olahan rumah tangga masih perlu disosialisasikan.

${ }^{18}$ Tim Lindsey, Hak Kekayaan Intelektual, Bandung: Alumni, 2005, hlm. 144.

19 Ibid., hlm. 145 
3) Koordinasi dan kerjasama yang sinergi antara para pihak dan upaya peningkatan penyebarluasan, pemahaman dan pemanfaatan sistem Hak Kekayaan Intelektual belum optimal dalam perlindungan merek dagang produk makanan.

Tujuan diadakan kerjasama antara Departemen Hukum dan HAM RI dengan Kementrian Negara Koperasi dan Usaha Kecil Menengah adalah:20

1) Meningkatkan pengetahuan dan pemahaman serta pemanfaatan sistim HKI khususnya merek dagang dikalangan pelaku UMKM.

2) Mewujudkan UMKM berorientasi HKI khususnya Hak Merek, memiliki kualitas dan daya saing yang tinggi dalam persaingan global.

3) Meningkatkan koordinasi dan kerjasama yang sinergis dan produktif antara para pihak dalam mengembangkan UMKM dan memberdayakan sistim Hak Kekayaan Intelektual ( HKI) nasional.

c. Pemberian Intensif Pembiayaan Pendaftaran Merek UMKM

Dasar hukum Keputusan Direktur Jenderal Hak Kekayaan Intelektual Kementerian Hukum dan Hak Asasi Manusia RI Nomor HKI-09.OT.03.01 Tahun 2013 tentang Insentif Hak Kekayaan Intelektual Bagi Sekolah Menengah Perguruan Tinggi, Usaha Mikro dan Usaha Kecil serta Warga Binaan Pemasyarakatan Tahun 2013. Pemberian insentif berupa pemberian pembiayaan pendaftaran pengajuan permohonan Hak Kekayaan Intelektual yakni merek baik berupa gambar, nama, kata, huruf-huruf, angka-angka, susunan warna atau kombinasi dari unsur-unsur tersebut yang memiliki daya pembeda dan digunakan dalam kegiatan barang atau jasa.

Adapun ruang lingkup pemberian insentif merek mencakup pengajuan permohonan pendaftaran merek untuk maksimal 3 (tiga) macam barang atau jasa dalam 1 (satu) kelas setiap permohonannya. Pemberian insentif ditujukan bagi Usaha Mikro dan Usaha Kecil dengan persyaratan: ${ }^{21}$

1) Membawa surat pernyataan yang menyatakan sebagai UMKM yang dibubuhi materai secukupnya

2) Syarat permohonan pengajuan pendaftaran berdasarkan undang-undang merek, yaitu: Mengisi formulir dalam bahasa Indonesia, Foto copy KTP (3 lembar), Akta Badan Hukum/TBN (2 rangkap dilegalisasi oleh Notaris), Contoh etiket merek ukuran minimal 2x2 cm, maksimal 9x9 cm (28 helai), Surat pernyataan disertai materai

3) Belum pernah mendapat bantuan atau insentif dari pihak manapun.

4) Karya yang dihasilkan memenuhi kriteria perlindungan hak kekayaan intelektual dan berguna bagi masyarakat.

\footnotetext{
${ }^{20}$ Andrew Betlehn, Prisca Oktaviani Samosir, Upaya Perlindungan Hukum Terhadap Merek Industri UMKM Di Indonesia, Law \& Jurnal Justice, Volume 3, Nomor 1, April 2018, hlm. 40.

21 lbid., hlm. 41.
} 
5) Pengantar yang berasal dari Kantor Wilayah Kementerian Hukum dan HAM, jika pengajuan permohonan melalui Kantor Wilayah Kementerian Hukum dan HAM.

6) Surat Rekomendasi yang berasal dari Kementerian atau Dinas jika berasal dari Kementerian atau Dinas.

\section{d. Pendaftaran Merek Kolektif Industri UMKM}

Di Indonesia pelaku UMKM seringkali memperjual belikan suatu barang atau jasa dengan suatu ciri khas yang sama oleh beberapa pelaku UMKM lainnya. Sehingga, pemerintah melalui UU No. 20 tahun 2016 tentang Merek dan Indikasi Geografis memfasilitasi perlindungan Merek secara kolektif. Berdasarkan penjelasan UU No. 20 tahun 2016 tentang Merek dan Indikasi Geografis, Merek kolektif adalah Merek yang digunakan pada barang dan/atau jasa dengan karakteristik yang sama mengenai sifat, ciri umum, dan mutu barang atau jasa serta pengawasannya yang akan diperdagangkan oleh beberapa orang atau badan hukum secara bersamasama untuk membedakan dengan barang dan/atau jasa sejenis lainnya.

Merek kolektif diatur dalam Article 7 bis the Paris Convention for the Protection of Industrial Property Rights (1883/1967). Berdasarkan Article 7 Paris Convention negara anggota harus menerima pendaftaran merek kolektif yang dimiliki oleh asosiasi dimana eksistensinya tidak bertentangan dengan negara hukum asal, meskipun asosiasi tersebut tidak memiliki suatu pendirian komersial atau industrial di negara tersebut. Setiap negara menilai suatu persyaratan tertentu dimana merek kolektif dilindungi atau mungkin ditolak pendaftarannya jika merek kolektif tersebut bertentangan dengan kepentingan umum.

Di Indonesia, merek kolektif diatur dalam Pasal 46 sampai dengan Pasal 51 UndangUndang Nomor 20 Tahun 2016 tentang Merek dan Indikasi Geografis. Tujuan penggunaan merek kolektif adalah untuk menyederhanakan penyelesaian permintaan pendaftaran. Misalnya, jika sepuluh pengusaha masing-masing memproduksi jenis barang atau jasa, maka mereka harus mengajukan permintaan pendaftaran untuk melindungi setiap barang atau jasa yang dimaksud. Padahal masing-masing barang atau jasa yang diproduksi dan diperdagangkan tersebut mempunyai karakteristik yang sama, maka dalam hal tersebut dimungkinkan untuk menggunakan satu merek saja. Terhadap semua jenis barang atau jasa, cukup diajukan satu permintaan pendaftaran merek untuk mereka gunakan secara kolektif. Dengan demikian, para pengusaha khususnya pelaku UMKM dapat menghemat biaya, waktu dan tenaga untuk memproses permintaan pendaftaran merek. ${ }^{22}$

Merek kolektif merupakan salah satu jalan keluar yang diberikan oleh pemerintah terhadap para pelaku usaha UMKM di Indonesia. Jika mengacu kepada bunyi pasal 1 angka 4, maka pada prinsipnya Merek kolektif adalah Merek yang dipergunakan oleh komunitas pelaku usaha yang memperdagangkan suatu produk barang

\footnotetext{
22 M. Yahya Harahap, Tinjauan Merek Secara Umum dan Hukum Merek di Indonesia Berdasarkan UndangUndang Nomor 19 Tahun 1992, PT Citra Aditya Bakti, Bandung, 1996, hlm. 604.
} 
ataupun jasa yang sama. Para pelaku usaha tidak perlu mendaftarkan atau membangun merek secara individual melainkan dibangun secara bersama melalui beberapa orang ataupun beberapa badan usaha.

Berdasarkan hasil penelitian serta analisis dan pembahasan yang telah penulis lakukan pada bab-bab terdahulu, berikut disajikan kesimpulan yang merupakan jawaban terhadap permasalahan dalam penelitian ini sebagai berikut:

1) Problematika Dalam Perlindungan Hak Kekayaan Intelektual Di Bidang Merek Terhadap Produk UMKM disebabkan pemahaman pelaku UMKM terhadap hak merek masih rendah/dangkal, dimana mereka hanya tahu bahwa pendaftaran merek harus dilakukan di Jakarta, yang membutuhkan biaya yang banyak dan waktu yang lama. Akan tetapi untuk segi pemahaman manfaat dan pentingnya pendaftaran merek ini para pelaku UMKM sebagian besar sudah cukup memahami. Selain itu kegiatan penyuluhan/sosialisasi dari instansi yang berwenang masih sedikit, disamping materi yang disampaikan dalam penyuluhan lebih pada manfaat Hak Kekayaan Intelektual khususnya hak merek sehingga hal ini yang membuat para pelaku UMKM hanya memahami bahwa pendaftaran merek harus dilakukan di Jakarta. Pemahaman-pemahaman di antara para pelaku UMKM masih banyak yang menjadi penyebab tidak didaftarkannya merek dagang mereka, beberapanya terkait budaya saling tolong menolong, budaya memaklumi adanya peniruan merek, budaya semakin banyak peniru maka semakin banyak peminat, serta masih terdapat beberapa pemahaman lain yang ada pada lingkungan pelaku UMKM..

2) Upaya dalam memberikan perlindungan merek terhadap industri UMKM adalah dengan cara mendaftarkan merek UMKM. Sehingga, dikarenakan kriteria pelaku usaha industri UMKM memiliki keterbatasan baik dari modal, aset maupun hasil penjualan tahunan jika dibandingkan dengan pelaku usaha Non-UMKM, oleh karenanya pemerintah memberikan kemudahan bagi pelaku industri UMKM untuk mendaftarkan merek, yaitu melalui kebijakan biaya registrasi merek UMKM yang lebih murah dibandingkan merek Non-UMKM, melakukan kerasama antara Dirjen KI Kementerian Hukum dan HAM dan Kementerian Koperasi dan UMKM, memberikan insentif pembiayaan pendaftaran pendaftaran merek UMKM, serta pendaftaran merek kolektif industri UMKM.

Berdasarkan hasil penelitian menurut peneliti masih ada kekurangan yang harus dipenuhi, untuk itu penulis memberikan saran-saran sebagai berikut;

1) Upaya mengatasi hambatan dalam pendaftaran merek dapat dilakukan oleh para pelaku usaha dan pemerintah. Upaya yang dilakukan oleh para pelaku usaha mengikuti berbagai penyuluhan dan sosialisasi tentang HKI, membuat nama merek yang lebih kreatif, mengecek merek yang telah terdaftar terlebih dahulu web Dirjen HKI apabila berencana mengajukan permohonan pendaftaran merek. Sedangkan upaya yang dapat dilakukan pemerintah yaitu mengadakan penyuluhan dan sosialisasi di setiap Kabupaten, memberikan fasilitas pembiayaan untuk pendaftaran merek. 
2) Perlunya koordinasi antara Pemerintah Pusat dan Pemerintah Daerah dalam rangka penerapan pendaftaran Merek dan Indikasi Geografis dengan melakukan langkah-langkah sosialisasi dan pelatihan bagi pelaku usaha/UMKM dalam hal pendaftaran. 


\section{Daftar Pustaka}

Abdulkadir Muhammad, Kajian Hukum Ekonomi Kekayaan Intelektual, Citra Aditya Bakti, Bandung, 2001.

Adrian Sutedi, Hak Atas Kekayaan Intelektual, Sinar Grafika, Jakarta, 2009.

Andriana Krisnawati dan Gazalba Saleh, Perlindungan Hukum Varietas Ban Tanaman dalam Perspektif Hak Paten dan Hak Pemulia, RajaGrafindo Persada, Jakarta, 2004.

B.N Marbun, Kekuatan \& Kelemahan Perusahaan Kecil, Pustaka Binaman Presindo, Jakarta, 1996.

Bambang Kesowo, Pengantar Umum Mengenai Hak Atas Kekayaan Intelektual (HAKI) di Indonesia, Persada, Semarang, 1995.

Candra Purnama, Perlindungan Hukum Produk Umkm Melalui HKI (Hak Kekayaan Intelektual), Staf Dinas Koperasi Dan UMKM, Jakarta, 2010.

Harsono Adi Suamarto, Hak Milik Intelektual Khusunya Paten, dan Merek, Akademik Presindo, Jakarta, 1990.

Helianti Hilman, dalam Emmy Yuhassarie, Hak Kekayaan Intelektual dan Perkembangannya, Pusat Pengkajian Hukum, Jakarta, 2004.

Ismail Saleh, Hukum dan Ekonomi, Gramedia Pustaka Utama, Jakarta, 1990.

Khoirul Hidayah, Hukum Hak Kekayaan Intelektual, Setara Press, Malang, 2017.

M. Yahya Harahap, Tinjauan Merek Secara Umum dan Hukum Merek di Indonesia Berdasarkan Undang-Undang Nomor 19 Tahun 1992, PT Citra Aditya Bakti, Bandung, 1996.

Peter Mahmud Marzuki, Penelitian Hukum edisi revisi, Kencana Pranada Media Group, Jakarta, 2015.

R. B. Simatupang, Aspek Hukum Dalam Bisnis, Rineka Cipta, Jakarta, 1995.

Richard Burton Simatupang, Aspek Hukum Dalam Bisnis, Asdi Mahasatya, Jakarta, 2003.

Saidin, Aspek Hukum Kekayaan Intelektual (Intellectual Property Right), Raja Grafindo Persada, Jakarta, 2003.

Soerjono Soekanto dan Sri Mamudji, Penelitian Hukum Normatif Suatu Tindakan Singkat, Raja Grafindo, Jakarta, 2007.

Sudargo Gautama, Segi-Segi Hukum Hak Milik Intelektual, Erasco, Bandung, 1990.

Suhardi, Hukum Koperasi Usaha Mikro, Kecil, dan Menengah di Indonesia, Akademia, Jakarta, 2012.

Syafrinaldi, Hukum Tentang Perlindungan Hak Milik Intektual Dalam Menghadapi Era Gllobalisasi, UIR Press, Pekanbaru, 2006.

Tim Lindsey, Hak Kekayaan Intelektual, Bandung: Alumni, 2005. 
Titik Sartika Partomo, Ekonomi Koperasi, Ghalia Indonesia, Bogor, 2009.

Tulus Tambunan, Perekonomian Indonesia Beberapa Masalah Penting, Ghalia Indonesia, Jakarta, 2003.

Asti Wulan Adaninggar, Hendro Saptono, Kholis Roisah, Perlindungan Produk Usaha Mikro Kecil Dan Menengah Terkait Hak Kekayaan Intelektual Dalam Menghadapi Masyarakat Ekonomi Asean, Law Journal, Volume 5, Nomor 3, Tahun 2016

Andrew Betlehn, Prisca Oktaviani Samosir, Upaya Perlindungan Hukum Terhadap Merek Industri UMKM Di Indonesia, Law \& Jurnal Justice, Volume 3, Nomor 1, April 2018

F. Yudhi Priyo Amboro, Problematika Pendaftaran Merek Untuk Usaha Mikro, Kecil dan Menengah di Kota Batam, Journal of Judicial Review, Volume XXI, Nomor 1, 2019

Iffan Alif Khoironi, Implementasi Pendaftaran Merek Sebagai Bentuk Perlindungan Hukum Pada Home Industry Eggroll, Law Journal, Volume 2, Nomor 2, 2013

Syafrinaldi, Perlindungan Merek Terkenal Di Indonesia Di Era Globalisasi, Jurnal Mahkamah, Volume. 2, Nomor 1, 2010

Undang-undang Dasar Tahun 1945

Undang-undang Undang-Undang Nomor 20 Tahun 2016 tentang Merek dan Indikasi Geografis

Undang-Undang Nomor 20 Tahun 2008 tentang Usaha Mikro, Kecil, dan Menengah

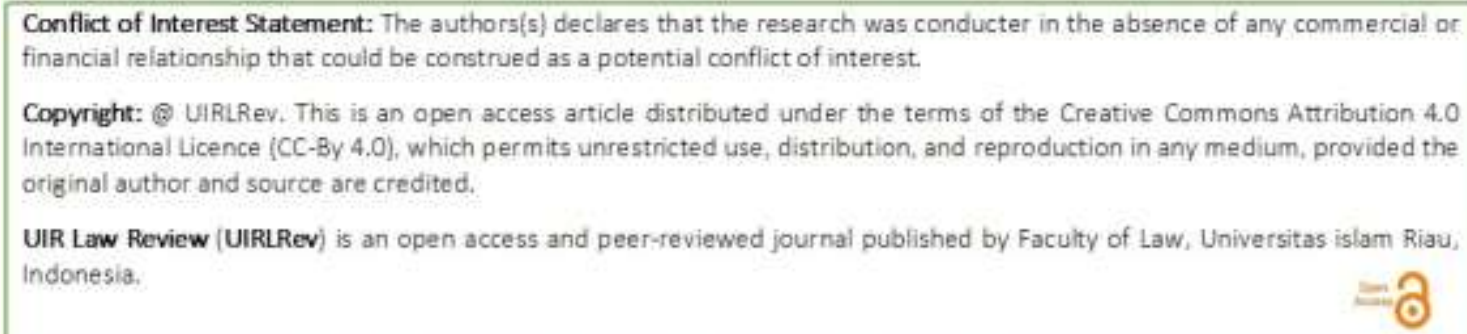

